УДК 631.4/18:631.48:631.18

(C) 2014

Крамарьов С. М., доктор сільськогосподарських наук, Крамарьов О. С., магістр

Інститут сільського господарства степової зони НААН

Писаренко П. В., доктор сільськогосподарських наук

Полтавська державна аграрна академія

Христенко А. О., кандидат сільськогосподарських наук

ННЦ Інститут грунтознавста та агрохімії імені О. Н. Соколовського НААН

Токмакова Л. М., кандидат сільськогосподарських наук

Інститут сільськогосподарської мікробіології та агропромислового виробництва НААН

Жученко С. І., кандидат сільськогосподарських наук,

Сироватко В. А., кандидат біологічних наук,

Сироватко К. В., інженер

Дніпропетровська філія Інституту охорони грунтів

\title{
ЗМІНА ВМІСТУ РУХОМОГО ФОСФОРУ В ГЕНЕТИЧНИХ ГОРИЗОНТАХ ЧОРНОЗЕМУ ЗВИЧАЙНОГО НА РІЛЛІ ВІДНОСНО ЦІЛИНИ В УМОВАХ ПІВНІЧНОГО СТЕПУ УКРАЇНИ
}

\section{Рецензент - доктор сільськогосподарських наук Г. П. Жемела}

Проаналізовано зміну вмісту рухомого фосфору в генетичних горизонтах чорнозему звичайного на ріллі відносно иілини в умовах північного Степу України за різних методів досліджень. Для точної діагностики фосфатного стану даних грунтів слід використовувати один із трьох методів: КарпінськогоЗам'ятіної (ДСТУ 4727), Мачигіна (ДСТУ 4114) або Олсена (ДСТУ ISO 11263). Встановлено, щзо реальна природна забезпеченість орного шару чорноземів звичайних фосфором відповідає межі низької та середньої забезпеченості изим елементом живлення рослин.

Ключові слова: вміст рухомого фосфору, мікроорганізми, рілля, иілина, чорнозем звичайний.

Постановка проблеми. Поряд 3 азотом другим за важливістю елементом мінерального живлення рослин є фосфор [24]. «Про це повинен пам'ятати кожен хлібороб...», - неодноразово наголошував у своїх наукових працях академік В. Д. Панніков [30]. Саме від рівня його засвоєння та метаболізму залежать визначально важливі етапи онтогенезу рослин та формування продуктивності агроценозів майже всіх зернових культур. Заради справедливості слід зазначити, що на основі багаторічних польових і вегетаційних дослідів Д. М. Прянішніков ще в 1924 році склав першу грунтово-агрохімічну карту колишнього СРСР, на якій він відносив чорноземну зону, в тому числі й чорноземи степової зони, до грунтів, які терміново потребують внесення фосфорних мінеральних добрив. Він писав, що в чорно- земах $\epsilon$ «..великий запас азоту, поки що вистачає калію: потрібно добавити лише один елемент - фосфор, щоб відновити чорнозем, виснажений тривалою культурою без добрив, яка розпочалася 3 часів хрещення Русі, або й ще раніше...» [31]. Це пов'язано з тим, що в більшості типів грунтів фосфор знаходиться в слаборозчинній мінеральній та недоступній рослинам органічній формах [29].

$\mathrm{y}$ чорноземах звичайних вміст мінеральних форм фосфору переважає над органічними, тому основну роль у фосфорному живленні рослин відіграють мінеральні форми фосфору. У грунтах, відмічає К. Є. Гінзбург [4], виявлено 205 фосфоровмісних мінералів, які всі є солями ортофосфорної кислоти. В основному, мінеральні сполуки фосфору представлені досить багатьма формами, що є переважно важкорозчинними, в основному, малорухливими формами і слабо доступними рослинам фосфатами. Мінеральні фосфати у грунті складаються з багатьох солей, які утворилися з ортофосфорної кислоти й є різними за хімічним складом і рівнем доступності для рослин. Фосфор входить до складу мінералів: фторапатиту $\mathrm{Ca}_{5} \mathrm{~F}\left(\mathrm{PO}_{4}\right)_{3}$, гідроксил апатиту $\mathrm{Ca}_{3}\left(\mathrm{PO}_{4}\right)_{2} \cdot \mathrm{Ca}(\mathrm{OH})_{2}$ та вівіаніту $\mathrm{Fe}_{3}\left(\mathrm{PO}_{4}\right)_{2} \cdot 8 \mathrm{H}_{2} \mathrm{O}$. 3-поміж них домінуюче положення займають різновидності мінералу апатиту, головним чином, фторапатиту. В лесовій материнській породі чорноземів звичайних фосфор міститься у вигляді фторапатиту $\mathrm{Ca}_{5}\left(\mathrm{~F}\left(\mathrm{PO}_{4}\right)_{3}\right.$ і кальцій гідро- 


\section{СІЛЬСЬКЕ ГОСПОДАРСТВО. РОСЛИННИЦТВО}

ксилапатиту $\mathrm{Ca}_{5}(\mathrm{OH})\left(\mathrm{PO}_{4}\right)_{3}$. У процесі руйнування цих первинних фосфоровмісних мінералів утворюються вторинні мінеральні сполуки фосфору, що містять у своєму складі різні солі ортофосфорної кислоти [33]. Мінеральні форми фосфору в грунті представлені солями ортофосфорної кислоти, в яких фосфатний аніон хімічно зв' язаний із катіонами $\mathrm{Ca}^{2+}, \mathrm{Mg}^{2+}, \mathrm{Fe}^{2+}, \mathrm{Al}^{3+}, \mathrm{Mn}^{2+}$ та ін., значна частина яких знаходиться в поглинутому стані на поверхні грунтових колоїдів. Характерною особливістю фосфатних грунтових сполук $\epsilon$ низька їх розчинність і слабка дисоціація на іони. Фосфатні іони добре фіксуються твердою фазою грунту й їх міграція в чорноземах звичайних вкрай обмежена. Інтенсивне хімічне поглинання характерне для солей ортофосфорної кислоти обумовлює слабку рухомість сполук фосфору. Швидкість їх дифузії в грунті незначна і варіюе в межах від $10^{-12} \mathrm{~m}^{2} /$ сек до $10^{-15} \mathrm{~m}^{2} /$ сек, що уповільнює засвоєння фосфору рослинами, внаслідок чого прикоренева зона рослин швидко виснажується на цей елемент мінерального живлення [41].

Органічні фосфати (нуклеїнові кислоти, фосфатиди, цукрофосфати та ін.), частка яких становить 10-50 \% від загального вмісту фосфору, недоступні для рослин і беруть участь у живленні тільки після їх гідролізу й відокремлення фосфору. Тобто, головним чином, фосфорорганічні сполуки грунту засвоюються рослинами лише після їх мінералізації. Проте частка вивільненого мікроорганізмами органічного фосфору, який бере безпосередню участь у мінеральному живленні рослин, незначна. Це пов'язано з тим, що в процесі розкладання фосфатовмісних органічних сполук за участі мікроорганізмів фосфор частково зв' язується ними, і лише $4 \%$ із загальної кількості фосфору звільняється й переходить у мінеральну форму після їх відмирання [42]. У зв'язку з цим виникає значний розрив між валовим вмістом фосфору в грунті і його доступною кількістю для рослин.

Засвоєння рослинами фосфатних аніонів із важкорозчинних сполук проходить лише з грунтового розчину: це - основне положення фізіології рослин. Засвоєння рослинами фосфору із важкорозчинних фосфоровмісних сполук проходить поступово, й фізіологи пояснюють це тим, що кореневі волоски своїми кислими виділеннями (ексудатами) переводять у розчин апатити й фосфорити не в повній мірі. У зв'язку з цим проблема фосфору в сучасному землеробстві $\epsilon$ досить гострою. Тому ми зобов'язані до цього елемента мінерального живлення відноситися 3 особливою увагою й турботою і постійно вести пошуки шляхів найбільш раціонального його використання в агроценозах зернових культур. Основним джерелом мінерального фосфору для рослин у чорноземах звичайних є одно- та двохвалентні аніони ортофосфорної кислоти. Серед наявних у цих грунтах фосфорних сполук рослини найлегше засвоюють добре розчинені у воді солі одновалентних катіонів $\mathrm{K}_{2} \mathrm{HPO}_{4} \mathrm{i} \mathrm{KH}_{2} \mathrm{PO}_{4}$, a також двозаміщені солі кальцію ортофосфорної кислоти $\mathrm{CaHPO}_{4}$.

Коренева система більш пристосована до поглинання аніона $\mathrm{H}_{2} \mathrm{PO}_{4}^{-}$i дещо гірше вона засвоюе $\mathrm{HPO}_{4}{ }^{2-}$. Тобто, рослини краще засвоюють розчинні в воді дигідрофосфати, ніж гідрофосфати, розчинені в слабких кислотах, що пов'язано з додатковими витратами енергії. До того ж аніон $\mathrm{H}_{2} \mathrm{PO}_{4}^{-}$легше адсорбується коренями, ніж $\mathrm{HPO}_{4}{ }^{2-}$, значення якого зростає за високих показників $\mathrm{pH}$, оскільки в розчині $3 \mathrm{pH}$ вище 7,2 цей аніон стає домінуючим іоном. Більшість проведених досліджень показали, що швидкість поглинання фосфору $\epsilon$ найвищою в діапазоні $\mathrm{pH}$ від 5,0 до 6,6, коли в грунтовому розчині переважає аніон $\mathrm{H}_{2} \mathrm{PO}_{4}{ }^{-}$[46].

Аніони $\mathrm{PO}_{4}{ }^{3-}$ не мають практичного значення для рослин, що пов'язано з низькою розчинністю карбонатів кальцію та магнію - $\mathrm{Ca}_{3}\left(\mathrm{PO}_{4}\right)_{2}$, яка мінімальна й становить 0,33 мг $\mathrm{P}_{2} \mathrm{O}_{5}$ в 1 літрі. У разі висихання частина дигідро- і гідрофосфатіонів переходить у фосфати кальцію та магнію й рівновага порушується, а за зволоження грунту, навпаки, відбувається перехід у розчин додаткової кількості фосфат-іонів - і рівновага відновлюється. Зауважимо, що в чорноземах звичайних фіксація аніонів фосфору в основному проходить у результаті їх хімічного зв' язування катіонами кальцію, магнію та алюмінію.

Дослідженнями професора Ф. В. Чирикова встановлено, що майже всі сільськогосподарські культури, за винятком тих їх видів (гречка, люпин, горох та ін.), у яких співвідношення $\mathrm{CaO} / \mathrm{P}_{2} \mathrm{O}_{5}$ більше 1,3 , здатні поглинати $\mathrm{P}_{2} \mathrm{O}_{5}$ iз $\mathrm{Ca}_{3}\left(\mathrm{PO}_{4}\right)_{2}$, розчиняючи фосфати своїми ексудатами або вивільняючи фосфор за рахунок інтенсивного поглинання 3 грунтового розчину катіонів кальцію, а ярі та озимі зернові колосові культури поглинають лише рухому його форму, поскільки назване вище співвідношення значно менше цього показника [40]. Ярі та озимі зернові культури (пшениця, жито, тритикале, ячмінь, кукурудза) слабо засвоюють важкорозчинні сполуки фосфору з грунту, тому вони добре реагують на внесення легкорозчинних форм фосфорних добрив, оскільки енергійно вбирають фосфор і менше - кальцій. За таких умов наявний 


\section{СІЛЬСЬКЕ ГОСПОДАРСТВО. РОСЛИННИЦТВО}

надлишок катіонів кальцію хімічно зв'язує рухомий фосфор у слаборозчинні фосфати. Тому в умовах Степу в грунтах серед елементів живлення рослин, що знаходяться в дефіциті, на першому місці стоїть фосфор, а вже потім азот, цинк і т. д. [18]. У цій зоні у прирості врожаю зернових культур частка дії фосфорних добрив висока (30-60\%), азотних значно менше (15$40 \%)$ і для калійних становить лише 0-20\%. Серед усіх форм фосфору найбільший вплив на врожай сільськогосподарських культур має рухома форма фосфатів. Особливо важлива роль рухомих форм фосфору проявляється, безумовно, на початку росту й розвитку рослин і особливо сильно відчувається на стадії проростків, тому його обов' язково вносять у грунт завчасно [16]. На пізніших фазах розвитку рослини слабше реагують на нестачу цього елемента живлення. Фосфор зменшує негативну дію надлишкового азотного удобрення, оптимізує використання рослинами мінерального азоту й підвищує ефективність дії азотних добрив. Однак водночас оптимальне забезпечення грунту рухомими формами цього елемента живлення є також важливим і впродовж всього онтогенезу рослин. У більшості типів грунтів рухомі форми фосфатів знаходяться в мінімумі й стримують подальший ріст продуктивності сільськогосподарських культур [25]. Тут доречним буде зауважити, що в Україні площа ріллі з низьким і середнім вмістом рухомого фосфору сягає 17812 га, або $57 \%$ загальної площі $[19,26]$. Саме через низьку забезпеченість грунтів доступним для рослин фосфором окупність фосфорних добрив досить висока: у середньому, 1 кг $\mathrm{P}_{2} \mathrm{O}_{5}$ забезпечує приріст 4-5 кг зерна. У найближчі роки в Україні внаслідок зниження вмісту фосфору в грунті зменшення продуктивності сівозмін сягне 2,2 зернової одиниці [18].

Парадокс проблеми фосфорного живлення рослин полягає в тому, що валові запаси фосфору в більшості грунтів в основному значні, однак на $40 \%$ площ орних земель світу продуктивність зернових культур лімітується нестачею рухомих форм фосфору [6, 23, 51, 54]. Це пояснюється тим, що в складі валових запасів фосфору в метровому шарі грунтів домінуюче положення займають слаборозчинні форми, а вміст рухомих форм, навпаки, незначний і не завжди відповідає потребам рослин [24, 36].

Аналіз останніх досліджень і публікацій, у яких започатковано розв'язання проблеми. Дослідження академіка Б. С. Носко свідчать, що родючість більшості грунтів в основному обме- жується недостатньою забезпеченістю їх рухомими формами фосфору [27]. За даними агрохімічного обстеження грунтів України, в 19661970 роках вміст фосфору у середньому становив 7,1 мг/100 г грунту [24]. Слід відмітити, що за вмістом фосфору грунтовий покрив відзначається більшою строкатістю порівняно 3 азотом. Це зумовлено, насамперед, властивостями лесових грунтоутворюючих порід та регіональними особливостями грунтоутворення, а також рівнем інтенсивності землеробства.

Крім того, за даними В. Е. Маккелви, на відміну від інших елементів органічної речовини грунту $(\mathrm{C}, \mathrm{H}, \mathrm{O}, \mathrm{N})$, які надходять у грунт переважно 3 атмосфери, основним первинним джерелом фосфору є грунтоутворююча материнська порода, яка не завжди в змозі забезпечити в достатній кількості грунтовий розчин рухомими формами фосфору [17]. Це пов' язано також ще й 3 тим, що фосфор за своїми хімічними властивостями має складну природу взаємодії з компонентами грунту. Ця обставина значною мірою ускладнює отримання об'єктивної оцінки забезпеченості грунту фосфором. Тому для уникнення його дефіциту вкрай важливим є своєчасне отримання інформації про вміст у грунті рухомих форм фосфору і підтримування оптимального рівня доступних для рослин його форм упродовж усього онтогенезу, внесенням фосфоровмісних добрив. Точне визначення показників рухомих сполук фосфору в грунті дає змогу ефективніше використовувати природні ресурси й прогнозувати ефективність дії фосфорних добрив [35]. Недостовірна інформація про фосфатний стан грунтів, навпаки, призводить до вкрай неефективного використання мінеральних добрив. Застосування методів визначення вмісту фосфору без урахування конкретних особливостей грунтів, а також недостатнє відпрацювання методичних аспектів діагностики живлення рослин призводить до викривлення оцінки стану родючості грунтів цілих зон [8]. Це пов'язано з тим, що більшість методів базується на використанні як екстрагентів розчинів сильних кислот, що свідчить про їх належність до так званих жорстких методів [34, 37, 38]. Використання цих методів на дуже кислих грунтах призводить до істотного заниження даних за рахунок сильного повторного поглинання $\mathrm{P}_{2} \mathrm{O}_{5}$ у процесі проведення аналізу, а в грунтах, що мають підвищений вміст апатитоподібних сполук, навпаки, - до істотного їх завищення. Навіть дуже слабка лужність грунтів викликає часткову нейтралізацію кислоти i, знову ж, - заниження результатів, які отримують [27].

3 вищевикладеного стає зрозумілим, що мето- 


\section{СІЛЬСЬКЕ ГОСПОДАРСТВО. РОСЛИННИЦТВО}

дично правильне визначення його вмісту в грунтовому розчині має надзвичайно важливе значення у проведенні розрахунків оптимальних доз внесення у грунт фосфорних добрив [24]. Щоб чітко уявити собі це, потрібно провести порівняння вмісту в грунті валових і рухомих форм фосфору. Проведене співставлення показало, що в чорноземах звичайних вміст валових форм фосфору становить 1100-1200 мг/кг грунту $(0,11-$ $0,12 \%)$. Вміст же рухомих його форм, визначених за методом Чирикова, які переходять у слабокислотні витяжки $0,5 \mathrm{~N}$ оцтової кислоти й частково беруть безпосередню участь у фосфатному живленні рослин, містяться в грунті в незначній кількості й становлять всього лише 98-167 мг/кг грунту $(8,2-13,9$ \%) від валового вмісту фосфору.

У науковій літературі поряд із терміном «рухомий» для виділення $з$ усієї сукупності фосфоровмісних мінеральних сполук доступні для рослин форми, часто використовують й інші терміни, які $є$ синонімами «засвоюваний», «лабільний» фосфор. Однак нечіткість цієї низки термінів заважає одержувати об'єктивну оцінку поживного режиму конкретного грунту. Поняття «рухомий» фосфор, калій і ін. помилково асоціюється 3 концентрацією конкретного елемента живлення рослин у грунтовому розчині, залежною від властивостей грунтів й інших чинників. Рухомість - це, швидше, міра доступності елемента рослинам. Вміст рухомих форм поживних речовин в екстенсивно використовуваній ріллі величина постійна для кожного з елементів [39]. Значення даних констант визначається фізикохімічними умовами, характерними для поверхні планети. Ілюзія різної природної забезпеченості різних типів орних грунтів і строкатості конкретного поля відносно рухомих фосфатів зумовлена недосконалістю нормативних і методичних аспектів діагностики фосфорного живлення рослин.

Відповідно до класичного визначення Д. М. Прянішнікова, «засвоюваний фосфор не є певною хімічною сполукою й не перебуває в готовому вигляді в грунті» [32]. Утім про те, що не все так просто, свідчить назва єдиного міжнародного стандарту ДСТУ ISO 11263, що встановлює спектрометричний метод визначення рухомого фосфору в грунтах [10], в якому акцент зроблено не на те, що визначаємо, а я́к визначаємо й за допомогою чо́го [38]. Слід відмітити, що через безперервний процес поглинання цього поживного елемента рослинами, концентрація доступного фосфору завжди низька [49]. Як відомо, рослини здатні поглинати фосфор із грунтового розчину навіть за невеликих його концентрацій, таких як 0,01-0,02 мг/л $\mathrm{P}_{2} \mathrm{O}_{5}$ [33]. До того ж у чорноземах звичайних вміст розчинних у воді фосфатів може відновлюватися за вегетаційний період більше ніж 100 разів [28]. У зв'язку з цим для нормального росту і розвитку рослин важливою $є$ не стільки висока його концентрація в грунтовому розчині, як здатність грунту поповнювати запаси рухомого фосфору $\mathrm{i}$ таким чином ліквідувати його дефіцит, що й спостерігається в польових умовах під час мінерального живлення рослин.

У даному випадку доступність фосфору в грунті для рослин залежить від його мобілізації та іммобілізації, які пов'язані з процесами розчинення чи осадження, сорбції й десорбції, мінералізації та біологічного закріплення його сполук [2]. Основним джерелом поповнення грунтового розчину рухомими формами фосфору $є$ валові його запаси, які зосереджені в материнській породі та в фосфоровмісних органічних сполуках грунту [26]. Одначе поряд із ними суттєву роль відіграють і водорозчинні сполуки фосфору, що надходять у грунт із мінеральними добривами.

Як уже відмічалося вище, в грунті валові запаси фосфору відносно високі. Так, в орному шарі чорноземів звичайних вміст валових форм фосфору становить 0,11-0,12 \%, а його валові запаси порівняно з азотом та калієм невеликі й варіюють у межах 5,4-5,5 т/га, а в метровому - 17,518,0 т/га [28], що значно нижче, ніж вміст у цих грунтах валових форм калію. Основна кількість валового фосфору міститься у верхньому (025 см) шарі грунту, що пов'язано 3 діяльністю рослин, активним поглинанням його грунтом $\mathrm{i}$ внесенням добрив. Внаслідок процесів біологічного переносу в гумусовому горизонті кількість його завжди більша, ніж у нижче розташованих горизонтах і материнській породі.

Забезпечення грунту фосфором може здійснюватись, в основному, лише за рахунок внесення фосфорних добрив. Слід зазначити, що в великих обсягах фосфорні добрива вносять у грунт лише економічно розвинуті країни, такі як Японія, США, Великобританія, Німеччина, Франція, Данія, Італія, Китай. До того ж у Німеччині навіть виникає проблема зафосфачування грунтів. Тому, на думку окремих авторів, за збереження цієї тенденції й надалі, запаси фосфору на Земній кулі можуть бути вичерпані вже через 60-80 років [48], і глобальний пік використання запасів фосфатної сировини, за прогнозами деяких дослідників [50], буде припадати на 2040 рік [19].

Статистичні дані свідчать, що за період 19661990 рр. обсяги застосування фосфорних добрив у землеробстві України постійно зростали. 


\section{СІЛЬСЬКЕ ГОСПОДАРСТВО. РОСЛИННИЦТВО}

Загальний баланс фосфору в 1971-1975 pp. був позитивним $\left(+3,9\right.$ кг/га $\left.\mathrm{P}_{2} \mathrm{O}_{5}\right)$, у наступні періоди (1976-1980 рр.) - +10,1 кг/га; 19811985 pp. - +15 кг/га; 1986-1990 pp. - +20,6 кг/га $\mathrm{P}_{2} \mathrm{O}_{5}$. За даними агрохімічного обстеження 19911995 pр. площі орних земель із підвищеним і високим вмістом фосфору зростали, а 3 низьким та середнім вмістом залишалися, порівняно 3 першим туром обстеження, на рівні $30 \%$ (19661970 рр.). Середньозважений вміст рухомого фосфору в Степу зріс від 6,7 мг на 100 г грунту до 9,3 мг на 10 г грунту.

Розпочинаючи з 1991 року рівень внесення фосфорних добрив різко зменшується - i в 1997 . дорівнював 4,1 кг/га $\mathrm{P}_{2} \mathrm{O}_{5}$. Дефіцит мінерального фосфору щорічно становить 15-20 кг/га, що зумовлює зниження вмісту фосфору у грунті на 0,40,5 мг/100 г грунту. Це поступово погіршує фосфатний режим чорноземів звичайних. Найнижчу кількість фосфорних добрив було внесено в 2000 р. - всього лише 2 кг/га $\mathrm{P}_{2} \mathrm{O}_{5}$. У 2001 та 2002 роках також було внесено невелику кількість цих добрив - 3 кг/га $\mathrm{P}_{2} \mathrm{O}_{5}$.

Поступове нарощування кількості внесених фосфорних добрив розпочалося 32004 p. 4 кг/га, аналогічну кількість було внесено і в 2005 році. У 2006 р. їх уже було внесено 7 кг/га $\mathrm{P}_{2} \mathrm{O}_{5}$, у 2007 p. - 10 кг/га $\mathrm{P}_{2} \mathrm{O}_{5}$. Із 2008 р. знову почала спостерігатися тенденція до зменшення обсягів їх внесення, - спочатку до 9 кг/га, а потім, в 2009 та 2010 рр. - близько 7 кг/га $\mathrm{P}_{2} \mathrm{O}_{5}$. Таке тривале внесення невеликих обсягів фосфорних добрив викликало поступове погіршення фосфатного режиму цих грунтів. Згідно з розробленим прогнозом, за повного припинення застосування фосфорних добрив вміст рухомого фосфору в грунтах знизиться на 3,0-3,2 мг/100 г грунту, а за таких умов господарювання грунти повністю втратять ту кількість фосфору, яка ними була накопичена за роки інтенсивної хімізації.

Тобто, за останні 25 років кількість внесеного фосфору на 1 га посівної площі знизилась із 40 кг діючої речовини до 3-4, азоту - 360 кг діючої речовини до 5-15, калію - 335 кг діючої речовини до 1-2. В останнє десятиліття виробництво фосфорних добрив в Україні різко скоротилося [43], зокрема у 2005 році знизилося на $22,9 \%$, що й призвело до різкого падіння рівня застосування мінеральних фосфорних добрив.

Україна має значну кількість родовищ фосфоритів (Волинська, Ізюмсько-Донецька групи родовищ та ін.), поклади яких приурочені до відкладів Нижнього Кембрію, Верхньої Крейди та Палеогену. В Західному Поліссі вже розвідано родовища зернистих та жовнових фосфоритів у складі агроруди, поклади якої залягають від 10 до 20 м, іноді ближче до поверхні [43]. Проте через невисоку концентрацію в них $\mathrm{P}_{2} \mathrm{O}_{5}$ ці фосфорити не переробляються на суперфосфат й інші водорозчинні фосфорні добрива, тому для ix виробництва в основному використовують імпортну сировину, що обумовлює високу їх собівартість.

У більшості ж випадків українські фосфорити містять у своєму складі близько $5 \% \mathrm{P}_{2} \mathrm{O}_{5}$, або 12-15\% фосфоритнокальцієвих мінералів та фосфатизованих їх порід і тому потребують проведення додаткового їх збагачення, після проведення якого суттєво зростатиме вартість фосфорних добрив. У зв'язку з цим дані фосфорити використовують лише на кислих грунтах Полісся та Карпат і на слабокислих грунтах лісостепової зони: у кислому середовищі слаборозчинні фосфати легко розчиняються [38]. На грунтах із нейтральною реакцією грунтового розчину фосфати практично не засвоюються корінням рослин, i ïx там практично не застосовують. На цих грунтах слід надати перевагу водорозчинним тукам.

У більшості ж країн світу, таких як, зокрема, й в Україні, дози внесення цих добрив невисокі, й винесення фосфору з грунту отриманими врожаями сільськогосподарських культур переважає його надходження з туками. В зв' язку з тим, щоб прослідкувати за змінами, що відбулися з рухомими формами фосфору в грунті, й порівняти ступінь їх рухомості в чорноземах звичайних на ріллі по відношенню до цілини й виникла необхідність у проведенні досліджень.

Мета і завдання досліджень: дослідити зміни вмісту рухомого фосфору в генетичних горизонтах чорнозему звичайного на ріллі відносно цілини в умовах північного Степу України.

Завдання досліджень: проаналізувати результати визначення рухомого фосфору в генетичних горизонтах чорнозему звичайного на ріллі відносно цілини в умовах північного Степу України за різних методів дослідження.

Матеріали і методи досліджень. Дослідження проведені на базі Ерастівської дослідної станції Інституту сільського господарства Степової зони НААН на чорноземі звичайному малогумусному важкосуглинковому на лесі. В орному шарі грунту міститься гумусу $3,8-4,1 \%$ (метод Тюрина), валового азоту $-0,22-0,23 \%$, фосфору $-0,12-0,13 \%$, калію $-2,0-2,1 \%$. Реакція грунтового розчину - нейтральна $\left(\mathrm{pH}_{\text {водн. }}=7,0\right)$.

Для визначення змін, які відбулися з рухомими формами фосфору в чорноземах звичайних під впливом тривалого їх використання в сільськогосподарському виробництві, було зроблено 


\section{СІЛЬСЬКЕ ГОСПОДАРСТВО. РОСЛИННИЦТВО}

два грунтових розрізи глибиною 2 м, шириною 3 м і довжиною 6 м кожний: перший на цілинній ділянці поблизу села Байківка П'ятихатського району Дніпропетровської області, а другий - на ріллі на відстані 300 м від першого.

Розпочинаючи 3 верхньої частини розрізів чеpeз кожні 5 см по всій глибині відбирали зразки грунту для визначення вмісту в них рухомих форм фосфору методом Чирикова, згідно 3 ГОСТ 26204 [5], і сольовим методом Карпінського-Зам' ятіної, згідно з ДСТУ 4727 [9].

Чисельність фосфатмобілізувальних бактерій у грунті визначали чашковим методом на поживному середовищі Муромцева 3 додаванням відповідного фосфату: $\mathrm{Ca}_{3}\left(\mathrm{PO}_{4}\right)_{2}-5$ г/л $\left(\mathrm{P}_{2} \mathrm{O}_{5}\right.$ 229 мг/100 мл), $\mathrm{C}_{3} \mathrm{H}_{5}(\mathrm{OH})_{2} \mathrm{PO}_{4} \mathrm{Ca}-6,0$ г/л $\left(\mathrm{P}_{2} \mathrm{O}_{5}\right.$ 203 мг/100 мл) [11].

Результати досліджень. Рілля, що становить 53,8 \% території України, належить до найбільш нестійких ландшафтів, а порушення сівозмін, засилля монокультури та різке зменшення обсягів внесення мінеральних і органічних добрив посилюють нестабільність агрохімічних показників агроландшафтів.

Ці умови призводять до дефіциту в грунті рухомих форм поживних речовин рослин, збільшення площ деградованих земель і породження екологічних проблем.

На етапі роздержавлення та перерозподілу земель порушилися сівозміни. Згідно з показниками Держкомстату України, посівні площі основних сільськогосподарських культур в Україні за 1990-2010 роки зменшилися більше ніж на 7,1 млн га і становлять 24,6 млн гектарів.

До того ж, посіви зернових і зернобобових культур залишаються на рівні 15,0 млн га (61 \%), проте посіви соняшнику невпинно збільшуються й становлять 4,57 млн га, або $19 \%$ загальної площі посівів.

Площа посівів ріпаку щорічно змінюється, але сягає 1,2-1,7 млн га (5-7 \%), а посіви кормових культур зменшилися на 9,4 млн га - на їхню частку припадає лише $10,5 \%$.

В Україні провідними науковими установами для кожного природно-сільськогосподарського регіону прийняті нормативи оптимального співвідношення культур у сівозмінах, а також терміни повернення окремих культур у сівозміні.

Лише у степових регіонах насичення соняшнику у сівозміні допускається 10-15\%, а ріпаку 5-12\%.

Зіставлення фактичних і нормативних показників співвідношення культур свідчить про масове недотримання сільськогосподарськими підприємствами науково обгрунтованих сівозмін або й взагалі їх відсутність. Посіви ж кон'юнктурних культур призводять до виснаження грунтів, утворення малопродуктивних земель i, в кінцевому підсумку, до їхньої деградації.

Площа таких земель щороку збільшується: вже нині налічують понад 1,4 млн гектарів.

Усе це свідчить про неефективне використання земель і відсутність надійної охорони останніх у сільськогосподарських підприємствах [15].

У даній статті наведені зміни вмісту рухомих форм фосфору, що відбулися в чорноземах звичайних на ріллі по відношенню до цілини.

Об'єктивно оцінити стан і встановити напрям трансформації сучасних еволюційних змін фосфорного режиму чорнозему звичайного дає змогу порівняння цілинних та орних земель за вмістом рухомих форм фосфору, визначених за методом Чирикова та сольовим методом Карпінського-Зам'ятіної.

Джерелом надходження фосфору на цілині $є$ відмерлі частини рослин, а на ріллі - добрива та пожнивно-кореневі залишки.

Проблема загострюється ще й безповоротністю втрат фосфору, обумовленою виносом цього елемента 3 грунту рослинами, оскільки накопичення його переважає в зерні, а не у вегетативній масі, яка після збирання врожаю в процесі мікробіологічного розкладу поповнює запаси недоступних для рослин елементів.

На ріллі основна маса фосфору вилучається 3 грунту разом із зерном, яке щорічно вивозиться 3 полів. За даними В. Г. Минеєва [20], в зерні зосереджена основна кількість фосфору (0,65$0,85 \%)$, яка майже в три-чотири рази перевищує його вміст у листостебловій масі $(0,20-0,28 \%)$ (табл. 1).

Тому залишена на полі вся листостеблова маса не в змозі повністю компенсувати винесеного з урожаєм зерна фосфору.

Для того, щоб у грунті не виникав від'ємний баланс фосфору, в нього потрібно повертати цей важливий елемент мінерального живлення 3 фосфоровмісними добривами.

Мобілізація фосфору з важкорозчинних природних сполук відбувається, переважно, під дією продуктів метаболізму мікроорганізмів.

Особливого значення набувають бактерії, що мають потенційну здатність перетворювати важкорозчинні фосфати грунту у доступну для рослин форму за рахунок продукування органічних кислот, які підкислюють грунтовий розчин, та дії специфічних ферментів - фосфатаз [1, 3, 12-14, $21,22]$. 
СІЛЬСЬКЕ ГОСПОДАРСТВО. РОСЛИННИЦТВО

\section{1. Порівняльна оцінка вмісту валового фосфору в основній та побічній продукції основних сільськогосподарських культур}

\begin{tabular}{|c|c|c|}
\hline \multirow{2}{*}{ Сільськогосподарська культура } & \multicolumn{2}{|c|}{ Вміст фосфору в сухій речовині, \% } \\
\cline { 2 - 3 } & зерні & листостебловій масі \\
\hline Пшениця озима & 0,85 & 0,20 \\
\hline Жито озиме & 0,86 & 0,25 \\
\hline Кукурудза & 0,57 & 0,30 \\
\hline Ячмінь ярий & 0,85 & 0,20 \\
\hline Овес & 0,85 & 0,35 \\
\hline Просо & 0,65 & 0,18 \\
\hline Сорго & 0,67 & 0,35 \\
\hline Горох & 1,0 & 0,35 \\
\hline Соя & 1,04 & 0,31 \\
\hline Соняшник & 1,39 & 0.65 \\
\hline Ріпак & 1,8 & 0,25 \\
\hline
\end{tabular}

2. Чисельність фосфатмобілізувальних бактерій у грунтовому розрізі на цілині та ріллі чорнозему звичайного

\begin{tabular}{|c|c|c|}
\hline \multirow{2}{*}{$\begin{array}{c}\text { Шари грунту } \\
\text { см }\end{array}$} & $\begin{array}{c}\text { Чисельність фосфатмобілізувальних бактерій, млн/г грунту } \\
\text { мінеральні фосфати грунту }\end{array}$ & $\begin{array}{c}\text { що розчиняють } \\
\text { органофосфати грунту }\end{array}$ \\
\cline { 2 - 3 } & \multicolumn{2}{|c|}{ Рілля } \\
\hline \multicolumn{3}{|c|}{ розчиняють } \\
\hline $5-5$ & $1,5 \pm 0,1$ & $5,4 \pm 0,4$ \\
\hline $5-10$ & $1,3 \pm 0,1$ & $2,3 \pm 0,1$ \\
\hline $10-15$ & $1,3 \pm 0,1$ & $2,7 \pm 0,2$ \\
\hline $15-25$ & $2,2 \pm 0,2$ & $2,4 \pm 0,2$ \\
\hline $25-35$ & $1,2 \pm 0,1$ & $4,5 \pm 0,3$ \\
\hline $35-45$ & $1,4 \pm 0,1$ & $1,0 \pm 0,0$ \\
\hline $45-65$ & $0,6 \pm 0,1$ & $1,0 \pm 0,1$ \\
\hline & $6,8 \pm 0,3$ & $9,8 \pm 0,6$ \\
\hline $0-5$ & $2,5 \pm 0,2$ & $4,7 \pm 0,4$ \\
\hline $5-10$ & $2,2 \pm 0,1$ & $2,2 \pm 0,2$ \\
\hline $10-15$ & $1,5 \pm 0,1$ & $2,0 \pm 0,1$ \\
\hline $15-25$ & $1,2 \pm 0,1$ & $2,5 \pm 0,3$ \\
\hline $25-35$ & $0,8 \pm 0,1$ & $1,2 \pm 0,1$ \\
\hline $35-45$ & $1,2 \pm 0,2$ & $0,9 \pm 0,0$ \\
\hline $45-65$ & \multicolumn{2}{|c|}{} \\
\hline
\end{tabular}

У ході досліджень нами встановлено, що в грунтовому розрізі на цілині та ріллі чорнозему звичайного (околиця с. Байківка П'ятихатського району Дніпропетровської області) найвищою чисельністю фосфатмобілізуючих бактерій характеризується верхній гумусовий горизонт цілини (табл. 2).

Виявлено, що чисельність бактерій, які розчиняють органофосфати грунту, була значно більшою порівняно 3 кількістю бактерій, що розчиняють мінеральні фосфати грунту.

Порівняльний аналіз вмісту рухомого фосфо- ру в грунтових профілях ріллі та цілини переконливо показав його накопичення у верхніх шаpax грунту в порівнянні 3 розташованими глибше.

Це передусім пов'язано з біологічною акумуляцією фосфору кореневими системами рослин, які за рахунок своїх ексудатів розчиняють фосфати кальцію й магнію, переводячи їх у гідро- та дигідрофосфати і нагромаджують цей елемент мінерального живлення в поверхневих горизонтах грунту. 
СІЛЬСЬКЕ ГОСПОДАРСТВО. РОСЛИННИЦТВО

\section{3. Вміст рухомого фосфору в різних ценозах чорнозему звичайного за даними кислотного} та сольового методів

\begin{tabular}{|c|c|c|c|c|}
\hline \multirow{2}{*}{$\begin{array}{l}\text { Шари } \\
\text { грунту, } \\
\text { см }\end{array}$} & \multicolumn{2}{|c|}{$\begin{array}{l}\text { Вміст рухомого фосфору } \\
\text { методом Чирикова, } \\
\text { мг } \mathrm{P}_{2} \mathrm{O}_{5} / \text { кг грунту }\end{array}$} & \multicolumn{2}{|c|}{$\begin{array}{c}\text { Вміст рухомого фосфору за методом } \\
\text { Карпінського-Зам'ятіної, } \\
\text { мг } \mathrm{P}_{2} \mathrm{O}_{5} / \text { дм }^{3}\end{array}$} \\
\hline & рілля & цілина & рілля & цілина \\
\hline $0-5$ & 167 & 163 & 0,19 & 0,14 \\
\hline $6-10$ & 167 & 112 & 0,18 & 0,13 \\
\hline $11-15$ & 169 & 92 & 0,18 & 0,10 \\
\hline $16-20$ & 168 & 96 & 0,17 & 0,09 \\
\hline $21-25$ & 172 & 88 & 0,14 & 0,09 \\
\hline $26-30$ & 164 & 83 & 0,19 & 0,08 \\
\hline $31-35$ & 137 & 80 & 0,15 & 0,04 \\
\hline $36-40$ & 112 & 78 & 0,11 & 0,04 \\
\hline $41-45$ & 92 & 77 & 0,11 & 0,09 \\
\hline $46-50$ & 94 & 75 & 0,11 & 0,09 \\
\hline $51-55$ & 107 & 64 & 0,10 & 0,06 \\
\hline $56-60$ & 54 & 79 & 0,10 & 0,12 \\
\hline $61-65$ & 53 & 88 & 0,08 & 0,10 \\
\hline $66-70$ & 59 & 53 & 0,07 & 0,09 \\
\hline $71-75$ & 53 & 58 & 0,11 & 0,07 \\
\hline $76-80$ & 62 & 39 & 0,10 & 0,07 \\
\hline $81-85$ & 56 & 41 & 0,10 & 0,11 \\
\hline $86-90$ & 54 & 36 & 0,10 & 0,10 \\
\hline $91-95$ & 50 & 35 & 0,12 & 0,08 \\
\hline $96-100$ & 51 & 34 & 0,12 & 0,07 \\
\hline $101-105$ & 50 & 34 & 0,11 & 0,11 \\
\hline $106-110$ & 50 & 35 & 0,10 & 0,11 \\
\hline $111-115$ & 50 & 38 & 0,13 & 0,11 \\
\hline $116-120$ & 48 & 38 & 0,12 & 0,12 \\
\hline $121-125$ & 48 & 39 & 0,12 & 0,12 \\
\hline $126-130$ & 48 & 39 & 0,11 & 0,11 \\
\hline $131-135$ & 49 & 39 & 0,11 & 0,10 \\
\hline $136-140$ & 51 & 40 & 0,12 & 0,10 \\
\hline $141-145$ & 52 & 40 & 0,12 & 0,11 \\
\hline $146-150$ & 49 & 41 & 0,13 & 0,10 \\
\hline $151-155$ & 50 & 40 & 0,12 & 0,10 \\
\hline $156-160$ & 53 & 40 & 0,12 & 0,10 \\
\hline $161-165$ & 57 & 40 & 0,11 & 0,08 \\
\hline $166-170$ & 62 & 42 & 0,13 & 0,08 \\
\hline $171-175$ & 73 & 42 & 0,13 & 0,07 \\
\hline $176-180$ & 77 & 44 & 0,12 & 0,06 \\
\hline $181-185$ & 69 & 45 & 0,12 & 0,06 \\
\hline $186-190$ & 73 & 48 & 0,13 & 0,10 \\
\hline $191-195$ & 74 & 52 & 0,13 & 0,10 \\
\hline $196-200$ & 78 & 55 & 0,13 & 0,09 \\
\hline
\end{tabular}




\section{СІЛЬСЬКЕ ГОСПОДАРСТВО. РОСЛИННИЦТВО}

Аніон $\mathrm{PO}_{4}{ }^{3-}$ у грунті міститься в органічних комплексах (нуклеопротеїди, фосфатиди) і в різних співвідношеннях 3 катіонами $\mathrm{Ca}^{2+}, \mathrm{Mg}^{2+}$, $\mathrm{Fe}^{2+}, \mathrm{Fe}^{3+}, \mathrm{Al}^{3+}$. Ці фосфати в різній мірі доступні кореням рослин.

Зміни вмісту загального фосфору у грунті на цілинних та орних ділянках грунту притаманні лише верхньому (0-10 см) шару - 0,164\% i 0,148 \%. Починаючи з шару грунту $10-20$ см та глибше по профілю, його запаси знаходилися на одному рівні. Тому в своїх дослідженнях основна наша увага зосереджена на рухомих формах фосфору, які (в більшості випадків) $є$ лімітуючим фактором для росту й розвитку рослин та формування урожайності сільськогосподарських культур.

Вивчення фосфатного стану чорнозему звичайного в грунтових профілях ріллі та цілини показало наступне: за вмістом рухомого фосфору (за методом Чирикова) грунти характеризуються високою забезпеченістю фосфором, відповідно, 167 мг $\mathrm{P}_{2} \mathrm{O}_{5} /$ кг грунту і 163 мг $\mathrm{P}_{2} \mathrm{O}_{5} /$ кг грунту (табл. 3), за методом КарпінськогоЗам'ятіної - грунти характеризуються лише середньою забезпеченістю фосфором.

Розбіжність в оцінці фосфатного стану грунту пояснюється наступним: проведеними нами дослідженнями було встановлено (табл. 4), що чорноземи важко-суглинкового і глинистого гранулометричного складу на лесових породах містять підвищену або високу кількість апатитоподібних сполук фосфору - понад 200 мг $\mathrm{P}_{2} \mathrm{O}_{5} /$ кг (фракція Са-Р, метод Чанга і Джексона [47]). Фосфор, що міститься в цих мінералах, рослинам безпосередньо не доступний, але частково екстрагується розчинами сильних кислот, у тому числі 0,5 н оцтовою кислотою (метод Чирикова згідно з ДСТУ4115) [8], саме це й призводить до істотного завищення оцінки фосфатного стану грунтів. Визначення $\mathrm{P}_{2} \mathrm{O}_{5}$ у цих грунтах за методом Карпінського-Зам'ятіної показує реальний природний вміст рухомого фосфору й відповідає так званому рівню динамічної рівноваги, тобто 0,04-0,06 мг/дм ${ }^{3}$ (табл. 4).

Вміст рухомого фосфору у досліджуваних зразках чорнозему звичайного дещо вище рівня динамічної рівноваги фосфатних систем грунтів 0,17-0,19 мг $\mathrm{P}_{2} \mathrm{O}_{5} / л$ у ріллі і 0,13-0,14 мг $\mathrm{P}_{2} \mathrm{O}_{5} /$ дм $^{3}$ - в шарі 10 см цілини (табл. 3). Для ріллі дане підвищення вмісту фосфору в грунті пояснюється наявністю залишкових фосфатів добрив.

Що стосується цілини, то можна зазначити наступне: завдяки комплексу біохімічних, хімічних, фізико-хімічних й інших грунтотворних процесів, характерних для верхнього гумусового горизонту цілинних і перелогових грунтів, їх фосфатні системи характеризуються підвищеною кількістю вільної енергіiі. Основним джерелом цієї енергіï, що компенсує виробіток ентропії при біологічних і хімічних процесах, $\epsilon$, безумовно, органічна речовина. Дані сполуки нейтралізують позитивні заряди на поверхні глинистих мінералів, зв'язують активні катіони заліза, алюмінію й блокують фіксацію аніонів фосфорної кислоти. Тому цей горизонт грунту характеризується, зазвичай, підвищеною або високою забезпеченістю фосфором.

Фосфатний стан нижніх горизонтів ріллі та цілини практично однаковий і відповідає рівню динамічної рівноваги. Наявність більш високого вмісту рухомого фосфору (за методом Карпінського-Зам'ятіної) в окремих шарах грунту $(0,10-$ 0,12 мг $\mathrm{P}_{2} \mathrm{O}_{5} /$ дм $\left.^{3}\right)$ створюється за рахунок наявності карбонатів кальцію.

\section{4. Фосфатний стан орного иару неудобрених чорноземів звичайних важкого транулометричного складу північного Степу Украйни}

\begin{tabular}{|c|c|c|c|c|c|c|}
\hline \multirow{2}{*}{$\begin{array}{c}\mathrm{P}_{2} \mathrm{O}_{5} \\
\text { валовий, } \\
\text { мг/кг }\end{array}$} & $\begin{array}{c}\text { Чирикова, } \\
\text { мг/кг }\end{array}$ & $\begin{array}{c}\text { Карпінського- } \\
\text { Зам'ятіної, } \\
\text { мг/л }\end{array}$ & $\begin{array}{c}\text { Р пухкий, } \\
\text { мг/кг }\end{array}$ & $\begin{array}{c}\text { Al-P, } \\
\text { мг/кг }\end{array}$ & $\begin{array}{c}\text { Fe-P, } \\
\text { мг/кг }\end{array}$ & $\begin{array}{c}\text { Са-Р, } \\
\text { мг/кг }\end{array}$ \\
\cline { 4 - 7 } & 107 & 0.06 & 4.7 & 55 & 78 & 245 \\
\hline 1230 & 89 & 0.03 & 5.0 & 37 & 8 & 250 \\
\hline 1330 & 103 & 0.05 & 2.3 & 42 & 49 & 170 \\
\hline 1370 & 115 & 0.06 & 3.0 & 64 & 12 & 276 \\
\hline- & 126 & 0.05 & 5.2 & 31 & 72 & 304 \\
\hline 1430 & 91 & 0.05 & 5.5 & 30 & 73 & 358 \\
\hline 1550 & 113 & 0.06 & 6.0 & 62 & 106 & 367 \\
\hline- & 106 & 0.04 & 2.8 & 50 & 68 & 221 \\
\hline
\end{tabular}




\section{СІЛЬСЬКЕ ГОСПОДАРСТВО. РОСЛИННИЦТВО}

Внаслідок появи цих сполук нейтральне значення сольової витяжки (pH-5,8) зсувається в лужну сторону, що підвищує її екстрагуючу здатність.

Вміст рухомих форм фосфору в грунті залежить від багатьох факторів, у тому числі й від рівня його зволоження, що пов'язано 3 різною активністю біоти. Так, у разі підсихання грунту вміст рухомих форм фосфору зменшується, а після зволоження спостерігається тенденція до його зростання. Ця закономірність досить часто спостерігається в посушливі роки, коли в разі висихання грунту доступність фосфору знижується через швидке формування нерозчинних комплексів аніонів $\left(\mathrm{PO}_{4}^{3-}, \mathrm{HPO}_{4}{ }^{2-}, \mathrm{H}_{2} \mathrm{PO}_{4}{ }^{-}\right)$iз катіонами ( $\mathrm{CaO}, \mathrm{Fe}, \mathrm{Al}$ та ін.) $[44,45]$ та за рахунок залучення його в органічні сполуки мікроорганізмами [52, 53]. Тому коефіцієнт використання фосфору 3 мінеральних добрив навіть за достатнього його внесення становить лише 10-20\%, тоді як азоту - до $50 \%$, калію - близько $70 \%$ [55].

Низька температура грунту $\left(<10^{\circ} \mathrm{C}\right)$ спричиняе нестачу фосфору для рослин навіть за високого їх вмісту в валовій формі. За низької температури підвищується в'язкість грунтового розчину й знижується інтенсивність його поглинання 3 грунтового розчину кореневою системою рослин. Підвищення температури в грунтовому розчині на $1-2{ }^{\circ} \mathrm{C}$ призводить до збільшення вмісту фосфору в грунтовому розчині на $2,0 \%$. За нестачі вологи засвоєння фосфору 3 грунту уповільнюється.

Для того, щоб простежити за нагромадженням рухомого фосфору, нами були створені сприятливі умови щодо зволоження $60 \%$ від повної вологоємкості грунту і сприятливий температурний режим $\left(28,5^{\circ} \mathrm{C}\right)$. За таких умов у термостаті проводилося компостування грунтових зразків, відібраних із різних генетичних горизонтів. У цих зразках через 10, 20 та 30 діб визначали вміст рухомих форм фосфору за методом Чирикова, а ступінь їх рухомості - за методом Карпінського-Зам'ятіної. Дослідження показали, що найбільш інтенсивно відбувалося накопичення рухомих форм фосфору в перші 10 діб, у меншій мірі - через 20 діб, а після 30-ти діб компостування спостерігалася тенденція до зменшення вмісту в грунті вищеозначених форм фосфору (табл. 5).

Для більш інформаційного аналізу процесів трансформування показників фосфорного балансу у чорноземах на ріллі необхідно залучити такий інтенсивний показник як фосфатний потенціал, який може бути виражений із розчинності монокальцій фосфату у рівноважному розчині гетерогенної системи: тверда фаза - грунтовий розчин.

\section{5. Вилив компостування на вміст $P_{2} O_{5}$ у зразках трунту, відібраних на цілині та староорній ділянці поля}

\begin{tabular}{|c|c|c|c|c|c|c|c|c|}
\hline \multirow{4}{*}{$\begin{array}{l}\text { Шари грунту, } \\
\text { см }\end{array}$} & \multicolumn{8}{|c|}{ Вміст $\mathrm{P}_{2} \mathrm{O}_{5}$} \\
\hline & \multicolumn{4}{|c|}{$\begin{array}{c}\text { за методом Чирикова, } \\
\text { мг/100 г грунту }\end{array}$} & \multicolumn{4}{|c|}{$\begin{array}{c}\text { за методом Карпінського-Зам' ятіної, } \\
\text { мг/дм }{ }^{3}\end{array}$} \\
\hline & \multicolumn{8}{|c|}{ термін компостування, діб } \\
\hline & до & 10 & 20 & 30 & до & 10 & 20 & 30 \\
\hline \multicolumn{9}{|c|}{ Цілинна ділянка поля } \\
\hline $0-5$ & 16,3 & 22,3 & 22,6 & 22,0 & 0,14 & 0,52 & 0,40 & 0,33 \\
\hline $6-10$ & 11,2 & 19,0 & 22,3 & 21,7 & 0,13 & 0,50 & 0,29 & 0,34 \\
\hline $11-15$ & 9,2 & 14,4 & 20,7 & 19,2 & 0,10 & 0,50 & 0,26 & 0,30 \\
\hline $16-20$ & 9,6 & 17,0 & 19,7 & 18,8 & 0,09 & 0,46 & 0,23 & 0,27 \\
\hline $21-25$ & 8,8 & 17,7 & 19,2 & 18,4 & 0,09 & 0,48 & 0,24 & 0,24 \\
\hline $26-30$ & 8,3 & 18,0 & 18,6 & 18,0 & 0,08 & 0,38 & 0,22 & 0,24 \\
\hline \multicolumn{9}{|c|}{ Староорна ділянка поля } \\
\hline $0-5$ & 16,7 & 22,9 & 25,9 & 27,7 & 0,19 & 0,58 & 0,32 & 0,35 \\
\hline $6-10$ & 16,7 & 18,3 & 26,7 & 28,9 & 0,18 & 0,56 & 0,31 & 0,34 \\
\hline $11-15$ & 16,9 & 22,6 & 26,2 & 27,9 & 0,18 & 0,50 & 0,31 & 0,32 \\
\hline $16-20$ & 16,8 & 22,9 & 25,9 & 27,7 & 0,17 & 0,62 & 0,30 & 0,29 \\
\hline $21-25$ & 17,2 & 23,6 & 25,5 & 27,4 & 0,14 & 0,54 & 0,29 & 0,26 \\
\hline $26-30$ & 16,4 & 24,7 & 25,3 & 26,2 & 0,19 & 0,52 & 0,31 & 0,25 \\
\hline
\end{tabular}


Додаток розчинності монокальцій фосфату обчислюють за формулою (1):

$\mathrm{DP}\left(\mathrm{Ca}\left(\mathrm{H}_{2} \mathrm{PO}_{4}\right)_{2}\right)=a_{\mathrm{Ca}^{2+}} \cdot a_{\mathrm{H}_{2} \mathrm{PO}_{4}^{-}}^{2}$,

де $a_{\mathrm{Ca}}^{2+}, a_{\mathrm{H}_{2} \mathrm{PO}_{4}^{-}}-$концентрація (активність) іонів кальцію та залишку ортофосфорної кислоти.

Формула (1) після знаходження квадратного кореня та логарифмування має вигляд:

$\lg \sqrt{\mathrm{DP}{\mathrm{Ca}\left(\mathrm{H}_{2} \mathrm{PO}_{4}\right)_{2}}}=0,5 \cdot \lg a_{\mathrm{Ca}^{2+}}+\lg a_{\mathrm{H}_{2} \mathrm{PO}_{4}}$

Якщо прийняти $-\lg a_{\mathrm{Ca}^{2+}}=p \mathrm{Ca},-\lg \mathrm{H}_{2} \mathrm{PO}_{4}=\mathrm{pH}_{2} \mathrm{PO}_{4}$, то права частина формули (2) може бути виражена як:

$$
0,5 \mathrm{pCa}+\mathrm{pH}_{2} \mathrm{PO}_{4} \text {. }
$$

Сума (3) є фосфатним потенціалом, який виражає здатність моно кальцій фосфату $\mathrm{Ca}\left(\mathrm{H}_{2} \mathrm{PO}_{4}\right)_{2}$ до розчинення. Застосовуючи рівняння (3), можна порівняти значення експериментально здобутих показників $\mathrm{pH}_{2} \mathrm{PO}_{4}$ реальних грунтових розчинів із показниками фосфатного потенціалу. Якщо значення $\mathrm{pH}_{2} \mathrm{PO}_{4}$ знайдених показників будуть більше відповідного показника фосфатного потенціалу, то динамічна рівновага $\mathrm{H}_{2} \mathrm{PO}_{4}^{-}$у грунтовому розчині формується більш важкорозчинною сполукою ортофосфорної кислоти, ніж монокальцій фосфат.

Для розрахунків значень $\mathrm{pH}_{2} \mathrm{PO}_{4}$ у грунтовому розчині розроблена схема, заснована на побудові регресійної залежності $\mathrm{pH}_{2} \mathrm{PO}_{4}$ від значень, сформованих $\mathrm{pH}$ у грунтовій витяжці $0,01 \mathrm{MCaCl}_{2}$.

Для побудови діаграм розчинності залучають ряд достатньо апробованих регресійних рівнянь (за Ліндсею і Морено):

Гідроксилапатит $\mathrm{pH}_{2} \mathrm{PO}_{4}=2,33 \mathrm{pH}-8,25$

Варіециіт $\mathrm{pH}_{2} \mathrm{PO}_{4}=10,7-\mathrm{pH}$

Октокальційфосфат $p_{2} \mathrm{PO}_{4}=1,67 \mathrm{pH}-6,24$

Штренгіт $\mathrm{pH}_{2} \mathrm{PO}_{4}=10,9-\mathrm{pH}$

Фторапатит $\mathrm{pH}_{2} \mathrm{PO}_{4}=2 \mathrm{pH}-4,12$

Дикальційфосфат $\mathrm{pH}_{2} \mathrm{PO}_{4}=\mathrm{pH}-2,54$

Прикладом принципів, які покладено в основу формування рівнянь (4), можуть бути розрахунки щодо дикальційфосфату. Для цього необхідно залучити поняття додатку розчинності:

$\mathrm{DP}\left(\mathrm{CaHPO}_{4} \cdot 2 \mathrm{H}_{2} \mathrm{O}\right)=a_{\mathrm{Ca}^{2+}} \cdot a_{\mathrm{HPO}_{4}^{-}} \cdot a^{2} \mathrm{H}_{2} \mathrm{O}$

Молекулярна маса цієї сполуки складає 172 , в тому числі Са - $24 \%, \mathrm{HPO}_{4}-56 \%, \mathrm{H}_{2} \mathrm{O}-21 \%$.

У 100 мл розчинника повністю розчиняється 20 мг дикальційфосфату, що відповідає молярному складу: $\mathrm{Ca}-4,65 \cdot 10^{-3}$ моль; $\mathrm{HPO}_{4}-1,12 \cdot 10^{-2}$ моль; $\mathrm{H}_{2} \mathrm{O}-4,19 \cdot 10^{-3}$ моль.

Значення в цілому додатка у рівнянні (5) становить $2,1710^{-7}$. Значення

$p\left(\mathrm{CaHPO}_{4} \cdot 2 \mathrm{H}_{2} \mathrm{O}\right)=-\lg \left(2.17 \cdot 10^{-7}\right)=6,66^{\circ}$

3 іншого боку,

$p\left(\mathrm{CaHPO}_{4}\right)=p \mathrm{Ca}+p\left(\mathrm{HPO}_{4}\right)=6.66$.

Залучивши константу рівноваги:

$k_{2}=\frac{\left[\mathrm{H}^{+}\right]\left[\mathrm{HPO}_{4}^{-2}\right]}{\left[\mathrm{H}_{2} \mathrm{PO}_{4}^{-}\right]}$,

отримуємо $p\left(\mathrm{HPO}_{4}\right)=p\left(\mathrm{HPO}_{4}\right)-\mathrm{pH}+\mathrm{pk}_{2}$.

$\mathrm{k}_{2}$ - це друга за рахунком константа рівноваги у процесі дисоціації ортофосфорної кислоти: $\left[\mathrm{H}_{3} \mathrm{PO}_{4}\right] \stackrel{k_{1}}{\longrightarrow}\left[\mathrm{H}^{+} \llbracket\left[\mathrm{H}_{2} \mathrm{PO}_{4}^{-}\right] ;\left[\mathrm{H}_{2} \mathrm{PO}_{4}^{-}\right] \stackrel{k_{2}}{\longrightarrow}\left[\mathrm{H}^{+} \llbracket \mathrm{HPO}_{4}^{-2}\right]\right.$.

$p k_{2}=7,21$.

$p \mathrm{Ca}^{2+}=2$ для $0,01 \mathrm{MCaCl}_{2}$.

Залучивши вираз $\mathrm{pPO}_{4} 3$ (7) до (6) 3 урахуванням $\mathrm{pk}_{2}$, отримаємо рівняння:

$\mathrm{pH}_{2} \mathrm{PO}_{4}=\mathrm{pH}-2.54$. 


\section{СІЛЬСЬКЕ ГОСПОДАРСТВО. РОСЛИННИЦТВО}

У наших дослідженнях була застосована наступна схема:

- 4 г грунтової наважки заливали 100 мл 0,01 M розчину $\mathrm{CaCl}_{2}$;

- розчином $\mathrm{HCl}$ встановлювали шість значень $\mathrm{pH}$ у кожній із витяжок відповідного горизонту 0-30,0 см, 50-70 см;

- після 1 години екстрагування витяжок відповідного горизонту на ротаторі визначали вміст фосфору у фільтраті у перерахунку на $\mathrm{P}_{2} \mathrm{O}_{5}$ та $\mathrm{H}_{2} \mathrm{PO}_{4}$;

- згідно з (3) розраховували значення $\mathrm{pH}_{2} \mathrm{PO}_{4}=-\lg a_{\mathrm{H}_{2} \mathrm{PO}}$ і будували графічний вираз залежності $\left(P\left(H_{2} \mathrm{PO}_{4}\right)=f(p H)\right)$. Регресійну формулу співвідносили з переліком (4). На рисунках 1-4 наведені результати графічних побудов.

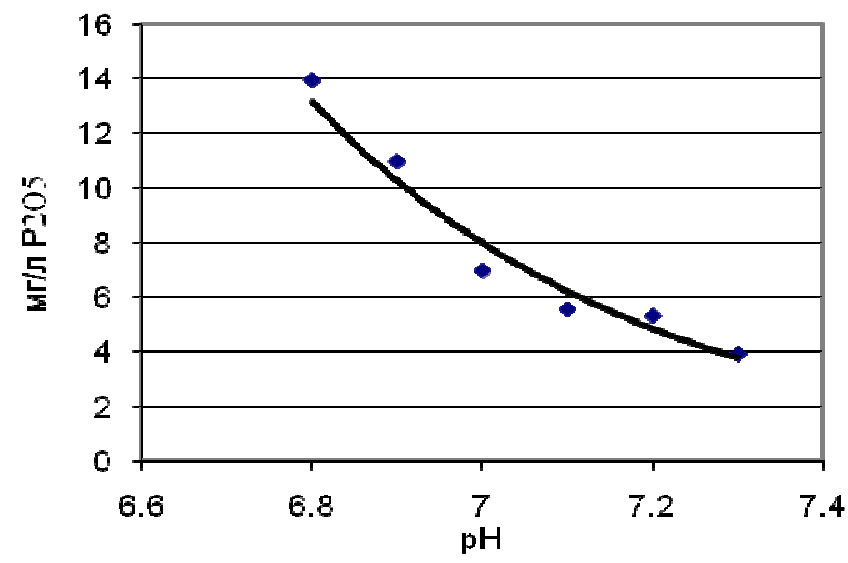

(a)

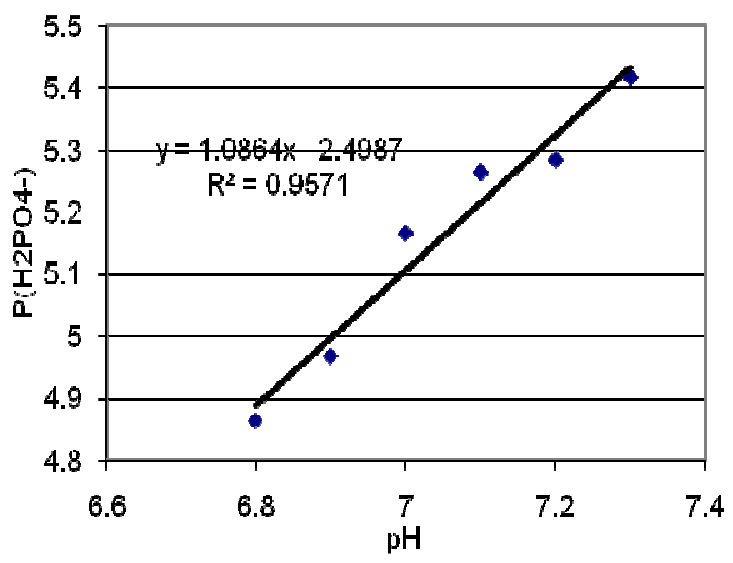

(б)

Рис. 1. Концентраційні залежнноті вмісту фосфатів у шарі трунту 0-30 см у рівноважному трунтовому розчині чорноземів звичайних на ріллі: $а$ - залежність вмісту $\mathrm{P}_{2} \mathrm{O}_{5}$ від значень рН;

б - залежність значень $\mathrm{pH}_{2} \mathrm{PO}_{4}$ відповідних витяжок від $\mathrm{pH}$

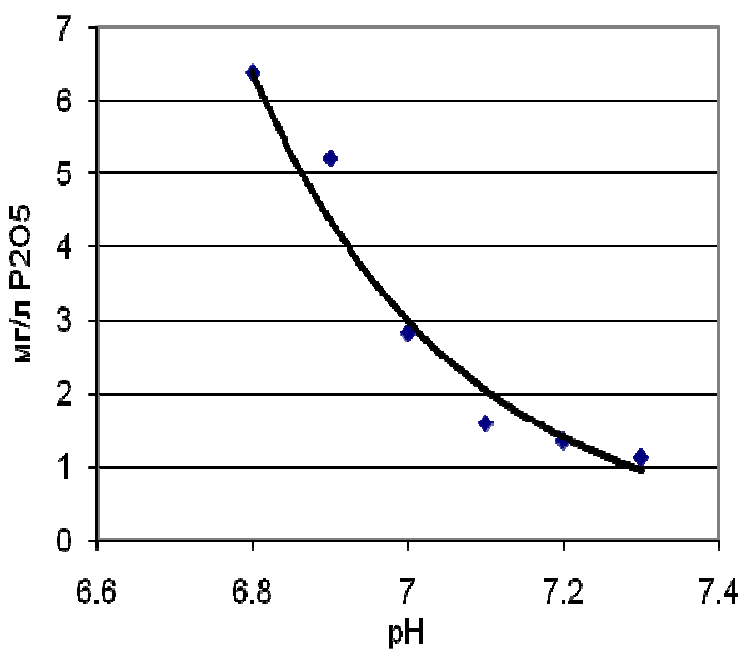

(a)

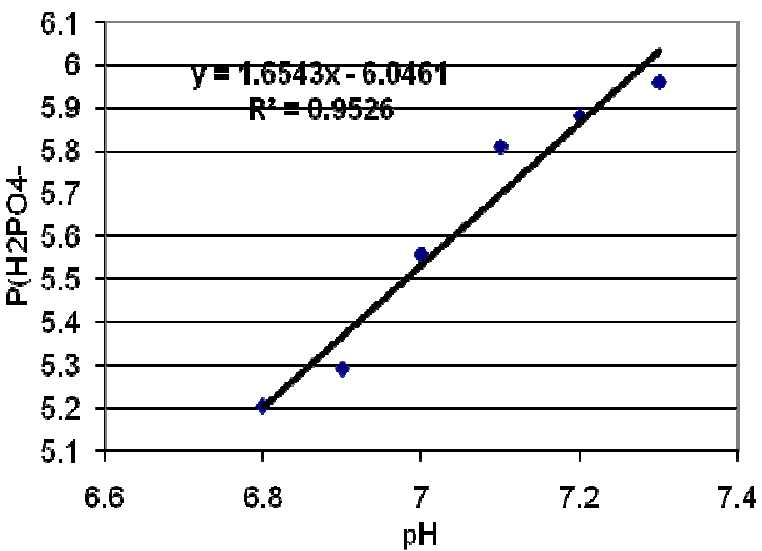

(б)

Рис. 2. Концентраційні залежсності вмісту фосфатів в шарі трунту 0-30 см у рівноважному трунтовому розчині чорноземів звичайних на цілині: a-залежність вмісту $\mathrm{P}_{2} \mathrm{O}_{5}$ від значень рН; б - залежність значень $\mathrm{pH}_{2} \mathrm{PO}_{4}$ відповідних витяжок від $\mathrm{pH}$. 


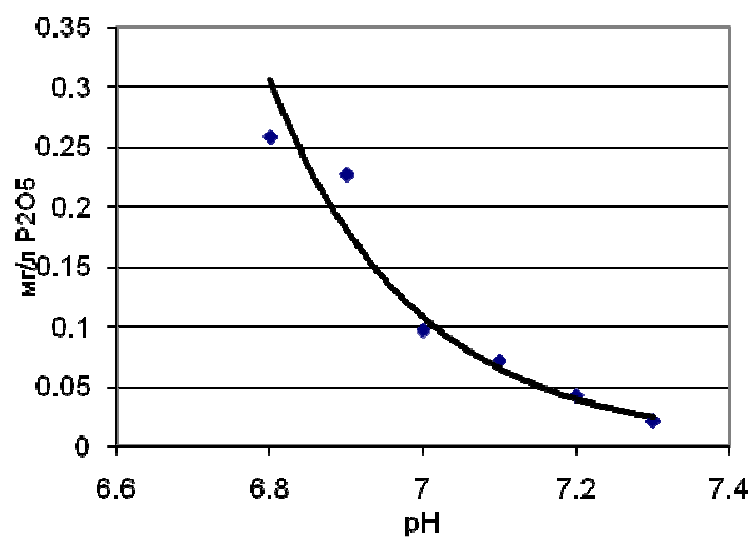

(a)

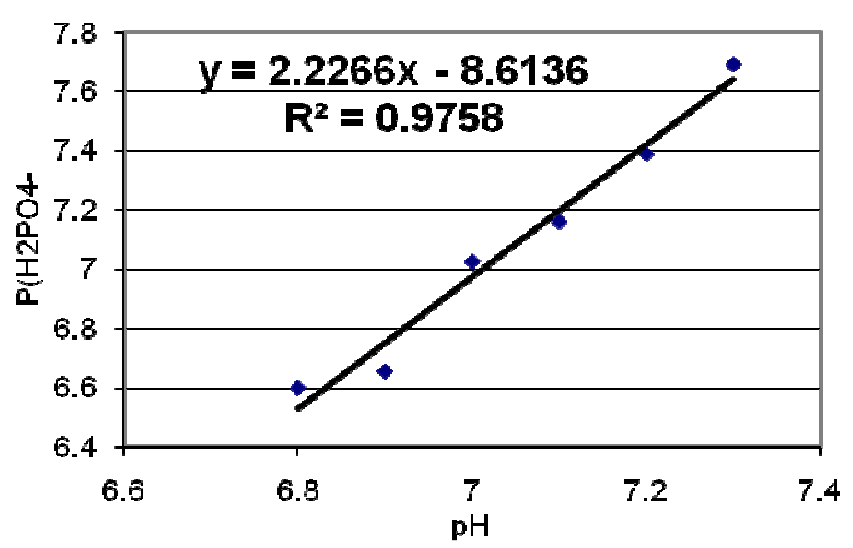

(б)

Рис. 3. Концентраційні залежності вмісту фосфатів у шарі трунту 50-70 см у рівноважному трунтовому розчині чорноземів звичайних на ріллі: $а$-залежність вмісту $\mathrm{P}_{2} \mathrm{O}_{5}$ від значень $\mathrm{pH}$; б - залежність значень $\mathrm{pH}_{2} \mathrm{PO}_{4}$ відповідних витяжок від $\mathrm{pH}$

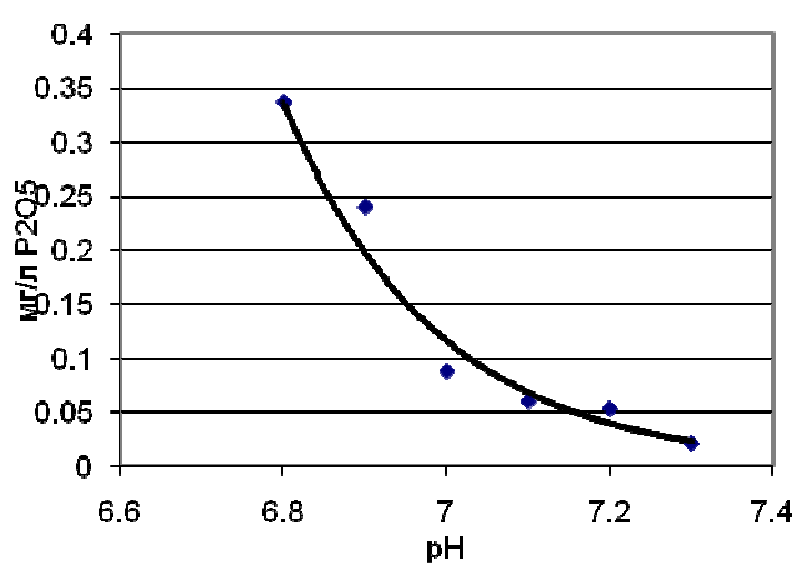

(a)

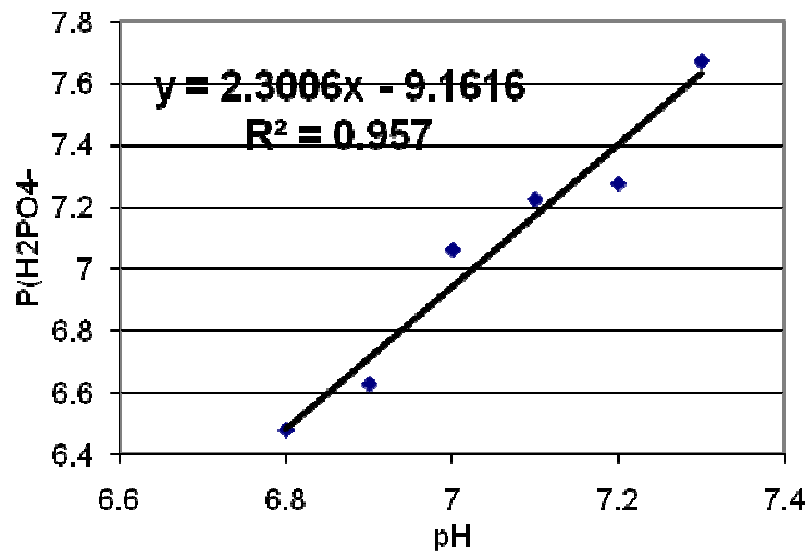

(б)

Рис 4. Концентраційні залежності вмісту фосфатів у рівноважному трунтовому розчині в шарі трунту 50-70 см чорноземів звичайних на цілині: а -залежність вмісту $\mathrm{P}_{2} \mathrm{O}_{5}$ від значень $\mathrm{pH} ; \sigma$ - залежність значень $\mathrm{pH}_{2} \mathrm{PO}_{4}$ відповідних витяжск від $\mathrm{pH}$

На підставі вищенаведеного, вміст рухомого фосфору в грунтах зони Степу визначають за одним із трьох методів: Карпінського-Зам'ятіної [9], Мачигіна [7] або Олсена [10].

Таким чином, дослідження, проведені 3 використанням сучасних методів грунтової діагностики, показали, що реальна природна забезпеченість фосфором чорноземів звичайних північного Степу України є невисокою, що лімітує отримання високих урожаїв сільськогосподарських культур. Внаслідок цього дані грунти так само потребують внесення фосфорних добрив, як i інші грунти України.
Точна інформація про трофічний стан грунтів, перш за все щодо макроелементів живлення рослин та динаміку їх родючості, дає змогу без істотних додаткових витрат більш ефективно використовувати добрива, підвищувати врожаї сільськогосподарських культур і якість одержуваної продукції.

\section{Висновки:}

1. Чорноземи звичайні на лесових породах важкого гранулометричного складу північного Степу України містять підвищену кількість апатитоподібних сполук. Використання будь-яких кислотних методів згідно з ГОСТ 26204 (метод 


\section{СІЛЬСЬКЕ ГОСПОДАРСТВО. РОСЛИННИЦТВО}

Чирикова) призводить до істотного штучного завищення оцінки фосфатного стану грунтів (на 40-80 мг $\mathrm{P}_{2} \mathrm{O}_{5} /$ кг грунту ).

2. Для діагностики фосфатного стану даних грунтів використовують один із трьох методів: Карпінського-Зам'ятіної (ДСТУ 4727), Мачигіна (ДСТУ 4114) або Олсена (ДСТУ ISO 11263).

3. Реальна природна забезпеченість орного шару чорноземів звичайних фосфором відповідає межі низької та середньої забезпеченості цим елементом живлення рослин.

4. Підвищеною або високою забезпеченістю фосфором характеризується лише орний шар грунту, що містить залишкові фосфати добрив, а також верхній гумусовий горизонт цілинних грунтів. Тому для отримання високих урожаїв із високою якістю на чорноземах звичайних північного Степу України необхідно вносити не менше фосфорних добрив, аніж на інших грунтах країни виходячи 3 даних грунтової діагностики.

\section{БІБЛІОГРАФІЯ}

1. Алексеева Р. П. Биологическая трансформация фосфорных соединений в почвах Западной Сибири / Р. П. Алексеева // Сельскохозяйственная биология. - 1983. - № 4. - С. 57-61.

2. Антипина Л. П. Фосфор в почвах Сибири: Автореферат дис. ... доктора сельскохозяйственных наук / Л. П. Антипина. - Омск, 1991. - 32 с.

3. Волкогон В. В. Рухомість фосфатів у кореневій зоні пшениці озимої за дії бактерій Rhizobium radiobacter / В. В. Волкогон, Л. М. Токмакова, А. О. Трепач // Вісник аграрної науки. - 2012. № 3 - C. 13-16.

4. Гинзбург К. Е. Фосфор основных типов почв СССР / К. Е. Гинзбург. - М. : Наука, 1981. $240 \mathrm{c}$.

5. ГОСТ 26204-91 Почвы. Определение подвижных соединений фосфора и калия по методу Чирикова в модификации ЦИНАО.

6. Гуляев Б. И. Фосфор как энергетическая основа процессов фотосинтеза, роста и развития растений / Б. И. Гуляев, В. П. Патыка // Агроекологічний журнал. - 2004. - № 2. - С. 3-9.

7. ДСТУ 4114-2002 Грунти. Визначення рухомих сполук фосфору і калію за модифікованим методом Мачигіна. - К. : Державний комітет 3 питань технічного регулювання та споживчої політики, 2002. - 11 с.

8. ДСТУ 4115-2002 Грунти. Визначення рухомих сполук фосфору і калію за модифікованим методом Чирикова. - К. : Національний стандарт України, 2002. - 5 с.
5. Рівноважна концентрація розчинних фосфатів у грунтовому розчині шару 0-30 см чорноземів звичайних на ріллі формується переважно за рахунок дикальцій фосфату $\mathrm{CaHPO}_{4}$, що пов' язано з залишками фосфорних добрив, тобто монокальцій фосфат $\mathrm{Ca}\left(\mathrm{H}_{2} \mathrm{PO}_{4}\right)_{2}$, який первинно потрапляє у грунт і з часом переходить до менш розчинної форми дикальцій фосфату. Рівноважна концентрація розчинних фосфатів у грунтовому розчині шару 0-30 см цілинних чорноземів формується переважно за рахунок октокальцій фосфату - також досить розчинної сполуки, але менш розчинної за дикальцій фосфат. Формування рівноважного розчину фосфатів у горизонті 50-70 см чорноземів звичайних на ріллі й цілині формується за рахунок гідроксилапатиту $\left[\mathrm{C}_{10}\left(\mathrm{PO}_{4}\right)_{6}(\mathrm{OH})_{2}\right]$.

6. За тривалий час сільськогосподарського використання чорноземів не відбулося значного трансформування основного джерела розчинних фосфатів у підорному горизонті.

9. ДСТУ 4727:2007 Якість грунту. Визначання рухомих сполук фосфору за методом Карпінського-Зам'ятної в модифікації ННЦ ІГА ім. О. Н. Соколовського. - К. : Держспоживстандарт України, 2008. -10 с.

10. ДСТУ ISO 11263-2001 Якість грунту. Спектрометричний метод. Визначання вмісту рухомих сполук фосфору в розчині гідрокарбонату натрію (ISO 11263:1994, IDT).

11. Експериментальна грунтова мікробіологія: Монографія / В.В.Волкогон, О.В.Надкернична, Л. М. Токмаковата [та ін.]; за наук. ред. В. В. Волкогона. - К. : Аграрна наука, 2010. - 464 с.

12. Илялетдинов A. Н. Биологическая мобилизация минеральных соединений / А. Н. Илялетдинов. - Алма-Ата : Наука, 1966. - 332 с.

13. Канівець B. I. Шляхи мікробіологічної мобілізації фосфатів у грунтах / В. І. Канівець, Л. М. Токмакова, І. М. Пищур // Грунтознавство. - 2006. - Т. 7, № 3-4. - С. 118-122.

14. Котелев В. В. Поступление фосфора $\mathrm{P}^{32}$ в клетки микроорганизмов и передача его растению / В. В. Котелев // Сб. : Изотопы в микробиологии. - М. : АН СССР, 1955. - С. 211-218.

15. Крамарев С. М. Эффективность использования фосфорных удобрений в агроценозах зерновых культур / С. М. Крамарев, С. В. Красненков, Л. Н. Токмакова [и др.] // Фосфор і калій у землеробстві. Проблеми мікробіологічної мобілізації. - Чернігів. Міжнародна науковопрактична конференція. Наукові доповіді. - КП «Друкарня» № 13. - 2004. - С. 56-65. 


\section{СІЛЬСЬКЕ ГОСПОДАРСТВО. РОСЛИННИЦТВО}

16. Лихочвор В. В. Добрівна альтернатива / В. В. Лихочвор. - «Зерно» (м. Київ), № 3. - 2008. - C. $42-45$.

17. Маккелви B. E. Фосфор в окружающей бреде / В. Е. Маккелви / Под ред. Э. Гриффита и др. - М. : Мир, 1977. - С. 24-37.

18. Медведєв В. В. Проблема фосфору в Україні та шляхи іiі розв'язання / В. В. Медведєв // Вісник аграрної науки. - 2000. - № 7. - С. 82-84.

19. Металіді В. С. Сировинна база фосфатів України / В. С. Металіді, І. В. Щепель // Мінеральні ресурси України. - 1999. - № 2. - С. 267269.

20. Минеев В. Г. Практикум по агрохимии. - М. : Из-во Московского у-та, 2001. - 687 с.

21. Мишустин Е. Н. Мобилизация минеральных фосфатов почвы и удобрений в процессе жизнедеятельности микроорганизмов / Е. Н. Мишустин, И. Т. Геллер, М. Синха // Известия TCXA. - 1972. - № 4. - С. 116-121.

22. Муромиев Г. С. Методы изучения растворения фосфатов микроорганизмами / Г. С. Муромцев // Микробиология. - 1957. - Т. 26. Вып. 2. - С. 172-178.

23. Никитишен В. И. Плодородие почвы и устойчивость функционирования агроэкосистем / В. И. Никитишен / Отв. ред. В. Г. Минеев. - М. : Наука, 2002. - 258 c.

24. Носко Б. С. Фосфатний режим грунтів i ефективність добрив / Б. С. Носко. - К. : Урожай, 1990. - 224 с.

25. Носко Б. С. Влияние состава и свойств почв на результаты определения содержания подвижного фосфора химическими методами / Б. С. Носко, А. А. Христенко // Агрохимия. 1996. - № 4. - C. 87-94.

26. Носко Б. С. Фосфорити як джерело живлення сільськогосподарських культур / Б. С. Носко, А. О. Христенко, В. І. Бабинін // Використання нетрадиційних сировинних ресурсів у сільському господарстві: Зб. наукових статей і доповідей. - Луцьк : Надстир'я, 1997. - С. 18-20.

27. Носко Б. С. Проблема фосфору в землеробстві України / Б. С. Носко, А. О. Христенко, В. П. Максимова // Вісник аграрної науки. 1999. - № 5. - C. 13-16.

28. Носко Б.С. Фосфор у землеробстві України / Б. С. Носко // Вісник аграрної науки. - № 7. 2004. - C. 14-17.

29. Носко Б. С. Післядія добрив на фосфатний режим чорноземів України / Б. С. Носко, В. І. Бабинін, Л. М. Бурлакова Л. М. [та ін.] // Вісник аграрної науки. - 2008. - № 12. - С. 17-22.

30. Панников В. Д. О высокой культуре земледелия и росте урожаїв / В. Д. Панников /
PACXH. - M., 2003. - 372 c.

31. Прянишников Д. М. О значении фосфатов для нашего земледелия и о расширении возможностей непосредственного применения фосфоритов. - В кн. : Фосфориты как непосредственное удобрение. - Д. : Научн. хим. техн. изд., 1924. - С. 19-30 (Труды НИУ, в. 12).

32. Прянишникова Д. М. Агрохимия. - М.-Л.: Сельхозгиз, 1934. - 399 с.

33. Соколов А. В. Агрохимия фосфора / А. В. Соколов. - М. : Наука, 1950. - 150 с.

34. Стахів М. П. Визначення рівнів доступного фосфору у грунті для високопродуктивних сортів озимої пшениці / М. П. Стахів, В.В.Швартау // Науковий вісник Ужгородського університету. - Серія : Біологія. - 2007. - Вип. 22. - С. 5-9.

35. Христенко А. О. Діагностика вмісту рухомих сполук фосфору в грунтах / А. О. Христенко // Вісник аграрної науки. - 1998. - № 4. - С. 21-25.

36. Христенко А. А. Проблема изучения фосфатного состояния почв / А. А. Христенко // Агрохимия. - 2001. - № 6. - С. 89-95.

37. Христенко А. О. Розробка стандарту України на методи визначення рухомих сполук фосфору і калію в грунтах / А. О. Христенко // Bicник аграрної науки. - 2003. - № 6. - С. 9-13.

38. Христенко А. О. Оцінка фосфатного стану грунтів на основі Міжнародного стандарту / А. О. Христенко, М. С. Лазебна // Вісник аграрної науки. - 2008. - № 10. - С. 16-19.

39. Христенко А. О. Рухомість «рухомих» елементів живлення рослин у грунті // Вісник аграрної науки. - 2009. - № 8. - С. 16-20.

40. Чириков Ф. В. Агрохимия калия и фосфоpa. - М. : Сельхозгиз, 1956. - 462 с.

41. Швартау В. В. Гербіциди. - Т. 2: Основи регуляції фітотоксичності та фізико-хімічні i біологічні властивості / В. В. Швартау. - 2009. $1046 \mathrm{c}$.

42. Швартау В. В. Особенности реакции растений на дефицит фосфора / В.В.Швартау, Б. И. Гуляев, А. Б. Карлова // Физиология и биохимия культурных растений. - 2009. - Т. 41, № 3. - C. 208-220.

43. Щегров Л. М. Перспективні шляхи виробництва фосфорних добрив в Україні / Л. М. Щегров, Н. М. Антрапцева, В. П. Кухарь [та ін.] // Вісник аграрної науки. - 2001. - № 9. - С. 13-15.

44. Abel S., Ticconi C. A., Delatorre C. A. Phosphate sensing in higher plants // Physiol. Plant. 2002. - V. 115. - P. 1-8.

45. Bolland M. D. A., Gilkes R. J. The chemistry and agronomic effectiveness of phosphate fertilizers // Nutrient use in crop production. - N.Y.: The Haworth Press, 1998. - P. 139-163. 
46. Buehler S., Oberson A., Rao I. M. et al. Furihata T., Suzuki M., Sakurai H. Kinetic characterization of two phosphate uptake system with different affinities in suspension cultured Catharanthus roseus protoplasts // Plant and Cell Physiol. - 1992. V. 33. - P. 1153-1157.

47. Chang, S.C. and M.L. Jackson. 1957. Fractionation of soil phosphorus. Soil Sci. 84: 133-144.

48. Hammond J. P., Bennett M. J., Bowen H. C. et al. Changes in gene expression in Arabidopsis shoots during phosphate starvation and potential for developing smart plants // Plant Physiol. - 2003. V. 132. - № 2. - P. 578-596.

49. Holford J. C. R. Soil phosphorus: its measurement, and its uptake by plants // Aust. J. Soil Res. - 1997. - V. 35. - P. 227-239.

50. Jasinski S. M. Phosphate rock. - 2006. - Statistics and In formation. - US Geological.

51. Ma J. R. Role of organic acids in detoxication of aluminum in higher plants // Plant Cell Physiol. -
2000. - V. 41. - P. 383-390.

52. Marschner P., Crowley D. E., Yang C. H. Development of specific rhizosphere bacterial communities in relation to plant species, nutrition and soil type // Plant Soil - 2004. - V. 261. - P. 199-208.

53. Marschner P., Grierson P.F., Rengel Z. Microbial community composition and functioning in the rhizosphere of three Banksia species in native woodland in Western Australia // Appl. Soil Ecol. 2005. - V. 28. - P. 191-201.

54. Rengel Z., Marschner $P$. Nutrient availability and manageme nt in the rhizosphere: exploiting genotypic differences // New Phytologist. - 2005.V. 168 . - P. 305-312.

55. Vance C. $P$. Update on the state of nitrogen and phosphorus nutrition. Symbiotic nitrogen fixation and phosphorus acquisition. Plant nutrition in a world of declining renewable resources // Plant Physiol. - 2001. - V. 127. - P. 390-397. 